\title{
Purification of Fish Gastric Hyaluronidase
}

\author{
Hiroshi Yamamoto* and Manabu KitamiKado*
}

(Received December 8, 1970)

\begin{abstract}
Crude hyaluronidase, prepared by extraction with dilute acetic acid from gastric mucosa of mackerel, was purified 185 fold by fractionation with ammonium sulfate, filtration on Sephadex G-100 column and chromatographies on CM-cellulose and DEAE-cellulose columns. The final preparation was free from $\beta$-glucuronidase and $\beta$ - $N$-acetylglucosaminidase, and was homogeneous on disc electrophoresis conducted with polyacrylamide gel. It showed a high specific activity of 10,000 turbidity reducing units of TOLKSDORF per milligram of its protein.
\end{abstract}

In the previous papers, ${ }^{1,2)}$ the authors reported the existence of a mucopolysaccharidase in the stomach of certain fishes which randomly cleaved $\beta$ - $\mathrm{N}$-acetylglucosaminidic bonds of hyaluronic acid. In the present work, the enzyme extracted from gastric mucosa of mackerel, Scomber japonicus, is purified until electrophoretically homogeneous by elimination of contaminated enzymes and inactive proteins.

\section{Materials and Methods}

The viscera of mackerel were obtained from a manufactory of dried fish in this district. Crude potassium hyaluronate was kindly supplied by Sansei Seiyaku Co. Ltd. (Japan) and was purified by the method of Dorfman et al. ${ }^{3)} p$-Nitrophenyl-N-acetyl- $\beta$-glucosaminide and $p$-nitrophenyl- $\beta$-glucuronide were purchased from Chugai Pharmaceutical Co. Ltd. (Japan). Sephadex, and CM-cellulose and DEAE-cellulose were obtained from Pharmacia (Sweden) and Seikagaku Kogyo Co. Ltd. (Japan), respectively. Hyaluronidase, $\beta$ - $\mathrm{N}$-acetylglucosaminidase and $\beta$-glucuronidase were assayed by the method of TOLKSDORF ${ }^{4)}$, LeVvy et al.$^{57}$ and NobunaGa ${ }^{6)}$, respectively. Protein was determined by the method of LowRy et al. ${ }^{\text {7) }}$ using bovine serum albumin as a reference standard. In order to examine the homogeneity of the enzyme preparations, polyacrylamide gel electrophoresis was performed at a constant current of $4 \mathrm{~mA}$ per tube $(5 \times 70 \mathrm{~mm})$ for 90 minutes.

\section{Results and Discussions}

Preparation of crude enzyme. Forty-eight grams of the gastric mucosa collected by scraping with a knife from 190 fish stomachs was homogenized in 10 volumes of $0.1 \mathrm{M}$ acetic acid solution, and the whole solution was allowed to stand overnight. After cen-

\footnotetext{
* Lab. Fish. Tech., Fac. Agr., Kyushu Univ., Fukuoka, Japan（山本 宏・北御門 学：九州大学 農学部水座製造学教室)
} 
trifugation, the resultant supernatant was submitted to the following purification procedures.

Purification procedures. All procedures were carried out between $0^{\circ}$ and $5^{\circ} \mathrm{C}$. Step 1. Ammonium sulfate fractionation. The supernatant was brought to $30 \%$ saturation with solid ammonium sulfate and allowed to stand overnight before centrifugation. The resultant supernatant was brought to $60 \%$ saturation by further addition of the solid salt and allowed to stand overnight. Then the resultant precipitate was collected by centrifugation, dissolved in a suitable amount of deionized water and thoroughly dialyzed against deionized water. The dialyzed solution was lyophilized, and the resultant substance, about $550 \mathrm{mg}$, was stored at $-15^{\circ} \mathrm{C}$.

Step 2. Gel filtration. The substance described above was dissolved in a small amount of $0.02 \mathrm{M}$ sodium phosphate buffer, $\mathrm{pH} 6.0$, containing $0.15 \mathrm{M}$ sodium chloride. The solution was applied to a column of Sephadex G-100, and hyaluronidase was eluted with the same buffer. As shown in Fig. 1, hyaluronidase was well separated from $\beta$ glucuronidase and a major inactive protein by the filtration, while the enzyme was partially overlapped with $\beta-\mathrm{N}$-acetylglucosaminidase. The fractions showing hyaluronidase activity were pooled, dialized against deionized water and lyophilized.

Step 3. CM-cellulose chromatography. The lyophilized amorphous substance was dissolved in a small amount of $0.1 \mathrm{M}$ acetate buffer, $\mathrm{pH} 4.0$. The solution was applied to

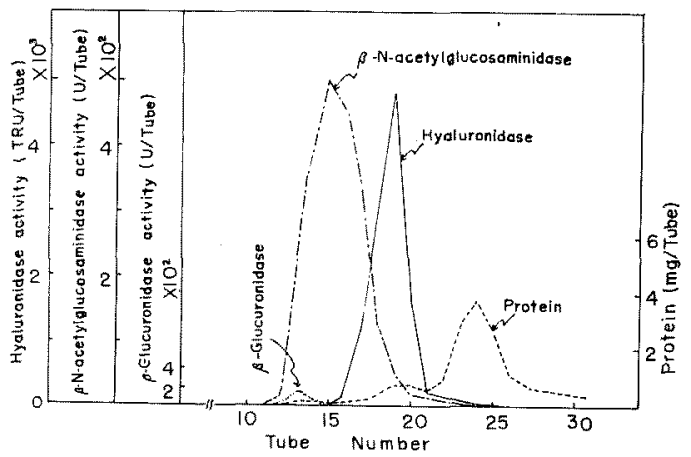

Fig. 1. Separation of hyaluronidase from $\beta$-glucuronidase, $\beta-\mathrm{N}$-acetylglucosaminidase and inactive major protein by Sephadex G-100 filtration.

A 52-mg portion of the ammonium sulfate precipitate was dissolved in $0.02 \mathrm{M}$ potassium phosphate buffer containing $0.15 \mathrm{M}$ sodium chloride, $\mathrm{pH} 6.0$. The solution was applied to a column $(1.6 \times 104 \mathrm{~cm})$ of Sephadex G-100. Elution was carried out with the same buffer. The flow rate was about $8.5 \mathrm{ml}$ per hour, and $6.0 \mathrm{ml}$ of the eluant was collected per tube. The contents of the tubes from No. 18 to 20 were collected, dialyzed against deionized water and lyophilized, and the amorphous substance was applied to the next procedure.

One unit of $\beta$-N-acetylglucosaminidase and $\beta$-glucuronidase is the amount of enzyme which liberates $1 \mu \mathrm{g}$ of nitrophenol from $p$-nitrophenyl- $\mathrm{N}$-acetyl- $\beta$-glucosaminide and $p$-nitrophenyl- $\beta$-glucuronide respectively in 30 minutes at $37^{\circ} \mathrm{C}$. One TRU of hyaluronidase is the amount of enzyme which reduces the turbidity obtained with $0.2 \mathrm{mg}$ of substrate to that obtained with $0.1 \mathrm{mg}$ of substrate in 30 minutes at $37^{\circ} \mathrm{C}$. 


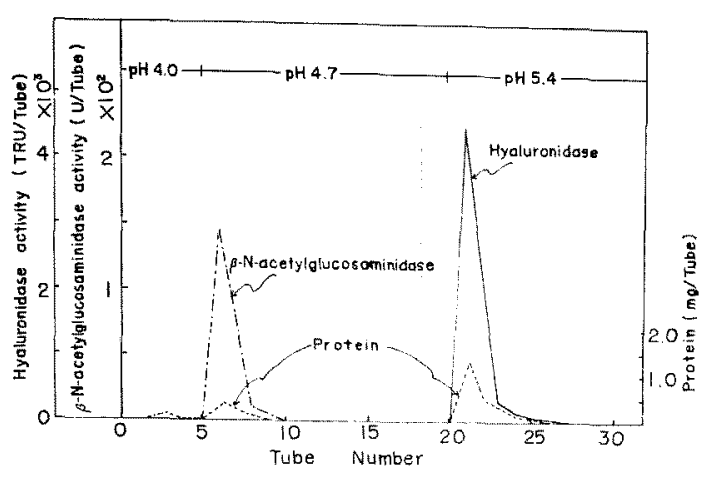

Fig. 2. Separation of hyaluronidase from $\beta$ - $N$-acetylglucosaminidase by $\mathrm{CM}$-cellulose column chromatography.

A 3.4-mg portion of the preparation from the Sephadex filtration was dissolved in $0.1 \mathrm{M}$ solution acetate buffer, $\mathrm{pH} 4.0$. The solution was applied to a column $(1.0 \times 3.5 \mathrm{~cm})$ of CM-cellulose which had been equilibrated with the same buffer. The stepwise elution was carried out with $0.1 \mathrm{M}$ sodium phosphate buffer changing the $\mathrm{pH}$ as indicated in the figure, and at the last step $0.1 \mathrm{M}$ sodium chloride was added so as to obtain a clear peak. The flow rate was about $10 \mathrm{ml}$ per hour, and $6.0 \mathrm{ml}$ of the eluant was collected per tube. The contents of the tubes from No. 21 to 22 were collected, dialyzed against deionized water and lyophilized, and the amorphous substance was applied to the next procedure.

a column of CM-cellulose which had been equilibrated with the same buffer, and the column was washed with the same buffer until the eluant contained no protein. Then, the enzymes were eluted with acetate buffer changing the $\mathrm{pH}$ in steps. The result shown in Fig. 2 indicates the good separation of hyaluronidase from $\beta$ - $\mathrm{N}$-acetylglucosaminidase by the chromatography. The fractions showing hyaluronidase activity were pooled, dialyzed against deionized water, lyophilized, and carried to the last procedure.

Step 4. DEAE-celluose chromatography. The lyophilized amorphous substance was dissolved in a small amount of $0.005 \mathrm{M}$ sodium phosphate buffer, $\mathrm{pH} 7.1$. The solution was applied to a column of DEAE-celluose which had been equilibrated with the same buffer, and the column was washed with the same buffer until the eluant contained no protein. As shown in Fig. 3, hyaluronidase was found in the eluant without adsorption on the column. Moreover, it was made sure that the adsorbed protein did not show any hyaluronidase activity, after it was eluted from the column with $0.1 \mathrm{M}$ sodium phosphate buffer, $\mathrm{pH} 5.5$, containing $0.1 \mathrm{M}$ sodium chloride. The fractions showing the enzyme activity were pooled, dialyzed against deionized water and lyophilized. The size of the columns being small, the above chromatographies had to be repeated several times to obtain about $5 \mathrm{mg}$ of the purified hyaluronidase from the stored ammonium sulfate precipitate. The final preparation was stored at $-15^{\circ} \mathrm{C}$, and employed for the determination of its properties as will be reported in the next paper.

The specific activities of the enzymes in the purification procedures are summarized in Table 1, and the electrophoretic mobilities of the preparations are shown in Fig. 4. 


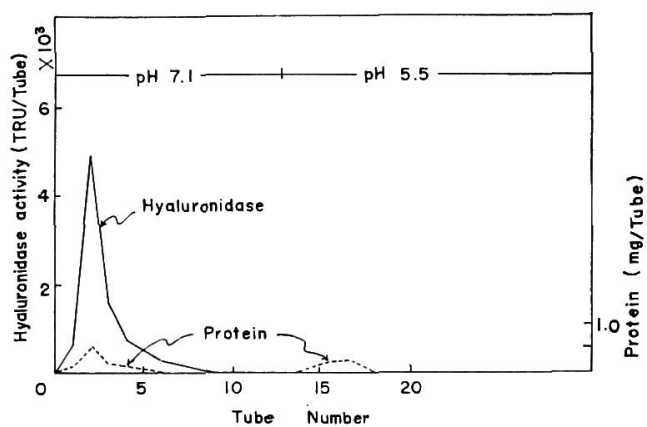

Fig. 3. Chromatogram of hyaluronidase on DEAE-cellulose column.

A 1.4-mg portion of the preparation from CM-cellulose chromatography was dissolved in $0.005 \mathrm{M}$ sodium phosphate buffer, $\mathrm{pH}$ 7.1. The solution was applied to a column $(1.0 \times 7.5 \mathrm{~cm})$ of DEAE-cellulose which had been equilibrated with the same buffer. The stepwise elution was carried out. The flow rate was about $10 \mathrm{ml}$ per hour, and $6.0 \mathrm{ml}$ of the eluant was collected per tube.

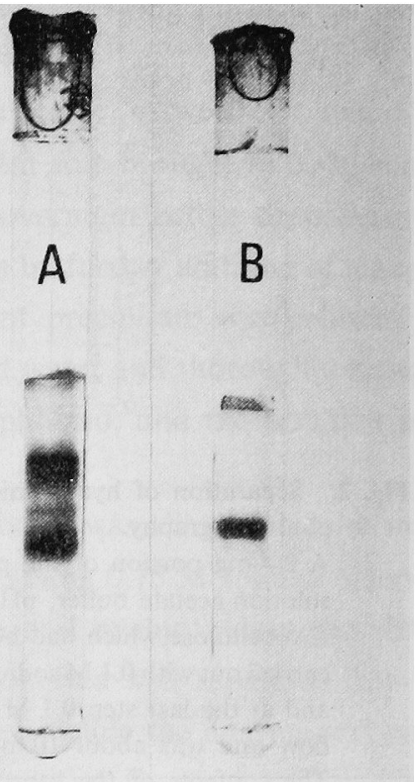

Fig. 4. Disc electrophoresis patterns.

A : Preparation by Sephadex G-100 filtration B: Final preparation

Disc electrophoresis was performed at $\mathrm{pH} 4.0$, and the gels were stained in a solution of 1 per cent 'Amido Black' in 7 per cent acetic acid.

Table 1. Purification of mackerel gastric hyaluronidase.

\begin{tabular}{|c|c|c|c|}
\hline $\begin{array}{l}\text { Purification } \\
\text { procedure }\end{array}$ & $\begin{array}{l}\text { Hyaluronidase } \\
\text { TRU/mg protein }\end{array}$ & $\begin{array}{l}\beta-\mathrm{N} \text {-acetyl- } \\
\text { glucomaminidase } \\
\text { U/mg protein }\end{array}$ & $\begin{array}{c}\beta \text {-Glucuronidase } \\
\text { U/mg protein }\end{array}$ \\
\hline 1. Crude extract & 54 & 172 & 5 \\
\hline $\begin{array}{l}\text { 2. Ammonium sulfate } \\
\text { fractionation }\end{array}$ & 208 & 3,908 & 9 \\
\hline $\begin{array}{l}\text { 3. Sephadex G-100 } \\
\text { filtration }\end{array}$ & 2,750 & 382 & 0 \\
\hline $\begin{array}{l}\text { 4. CM-cellulose } \\
\text { chromatography }\end{array}$ & 4,752 & 0 & 0 \\
\hline $\begin{array}{l}\text { 5. DEAE-cellulose } \\
\text { chromatography }\end{array}$ & 10,000 & 0 & 0 \\
\hline
\end{tabular}

The final preparation was electrophoretically homogeneous, and showed 185 times as much specific activity as that of the original crude extract.

\section{Acknowledgments}

The authors wish to thank Professor M. Toyomizu for many helpful suggestions and Sansei Seiyaku Co. Ltd. for a gift of a lot of potassium hyaluronate. 


\section{References}

1) M. Kitamikado and H. Yamamoto: This Bull., 35, 466-470 (1969).

2) M. Kitamikado and H. Yamamoto: ibid., 36, 385-390 (1970).

3) A. Dorfman and A. Cifonelli: in "Methods in Enzymology" (S.P. Colowick and N.O. KaPlan, ed.), Vol. 3, 22-24, Academic Press, New York (1957).

4) S. Tolksdorf: in "Methods of Biochemical Analysis" (D. Guick, ed.), Vol. 1, 425-457, Interscience Publishess, New York (1954).

5) G. A. Levvy and J. Conchie: in "Methods in Enzymology" (V. Ginsburg, ed.), Vol. 8, 571-584, Academic Press, New York and London (1966).

6) M. NoBUnAGA: Fukuoka Acta Chemica., 52, 300-311 (1961).

7) O. H. Lowry, N. J. Rosebrough, A. L. Farr and R. J. Randall: J. Biol. Chem., 193, 265-275 (1951). 